\title{
Exhaust Gas Analysis of 30kva Tata In Contrast To 30kva Perkins Generator (S)
}

\author{
Abubakar Danjuma Maiwada (Mechanical Engineer) \\ Physical Planning and Maintenance Department Northwest University, Kano Nigeria
}

\begin{abstract}
This paper is aimed at analyzing exhaust components from TATA and PERKINS diesel engine generators. Exhaust gas analyzer is used in performing the analysis, and a printer from the analyzer is used in printing the value obtained from the analysis. Analysis and discussion is then made based on the details obtained from the analyzer printout. Also, the exhaust gas analysis shows that, carbon monoxide value for TATA is 279ppm and for PERKINS, it is 494ppm, showing higher carbon monoxide emission value from PERKINS generator exhaust. In $\mathrm{g} / \mathrm{kWh}$, TATA value is $0.70 \mathrm{~g} / \mathrm{kWh}$ and PERKINS value is $1.17 \mathrm{~g} / \mathrm{kWh}$ as seen in the appendix. It is observed that both TATA and PERKINS emit far below the emission limit which is $11.2 \mathrm{~g} / \mathrm{kWh}$, and as such making both fit for use.
\end{abstract}

Significance: TATA and PERKINS generators release toxic gases into the atmosphere, which have adverse effect on both climate change and public health. Analyzing the exhaust gases will help in coming up with ways and different strategies of reducing these effects to the bearest minimum.

Keywords: Exhaust gas analyzer, emission, Volume, Tata, Perkins.

\section{Introduction}

All heat engines absorb heat from high temperature to perform some mechanical work and discard or reject some heat at a lower temperature. As far as the engine is concerned, the discarded or rejected heat is wasted.

In internal combustion engine, the waste heat is that discarded in the hot exhaust gases and the cooling system. When the system is carried through a cyclic process, its initial and final internal energies are equal. For cyclic process, the first law of thermodynamics is used

$\mathrm{U} 2-\mathrm{U} 1=0=\mathrm{Q}-\mathrm{W}$

So, $\mathrm{Q}=\mathrm{W}$

Therefore, the net heat flowing into engine in a cyclic process equal the net work done by the engine.

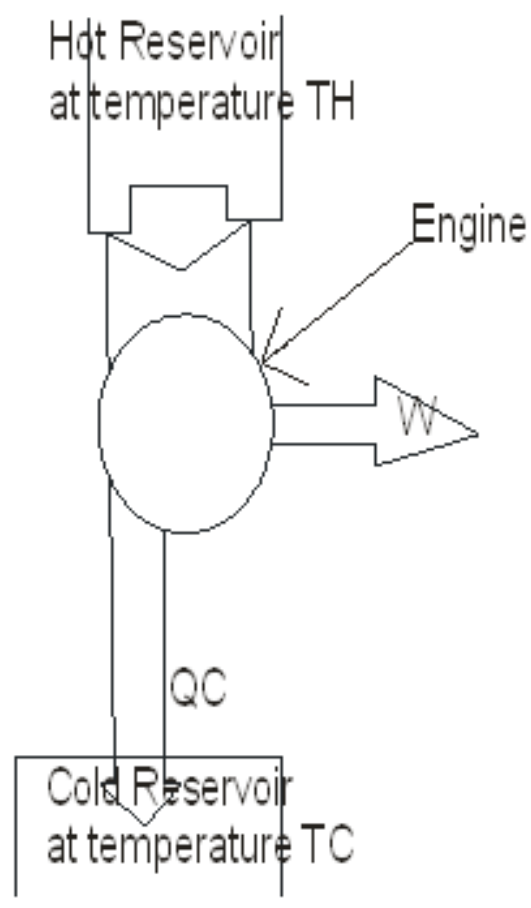

Fig.1.0 Heat Engine 
$\mathrm{W}=\mathrm{QH}+\mathrm{QC}$

$=/ \mathrm{QH} /-/ \mathrm{QC} /$

The amount of heat $\mathrm{QH}$ supplied to the engine by the hot reservoir is proportional to the width of the incoming pipeline at the top of the diagram. The width of the outgoing pipeline at the bottom is proportional to the magnitude /QC/ of the heat rejected in the exhaust.

\section{Experimentation And Results}

The analyzer is a complete portable device consisting of handset remote, standard probe, water trap, particle filter, oxygen sensor, charging wire, battery, printer, thermocouple, charging socket, light emitting diode (LED), pressure ports and some sensors as seen in the picture below.

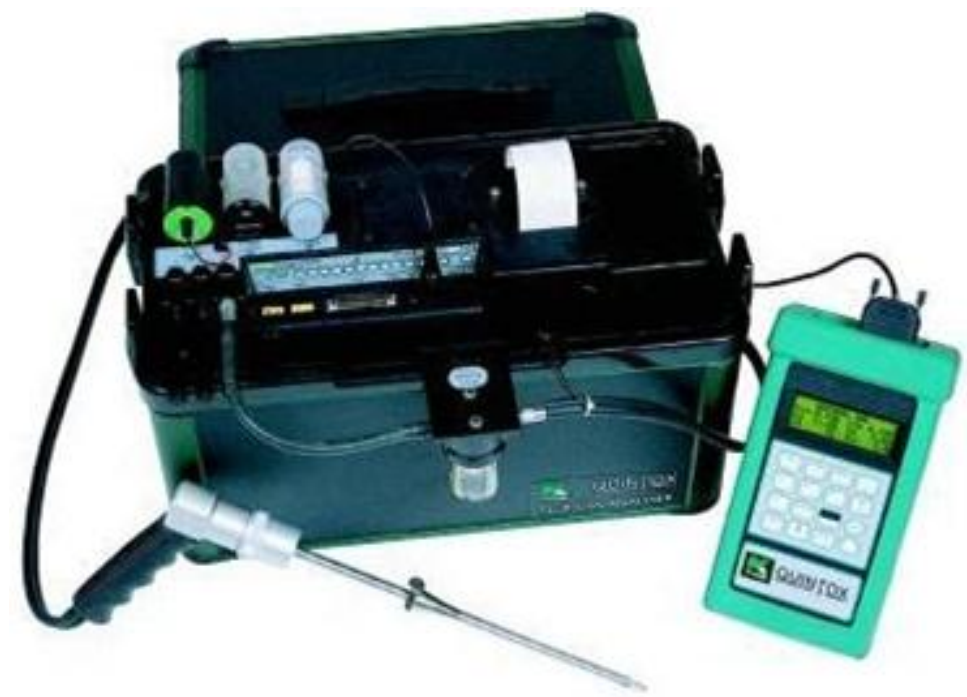

Fig.2.0 Exhaust Gas Analyzer

Before use, the analyzer was allowed to charge fully until the LED light shows green. After fully charging it, it was then taken to the site where the generator is. Before switching the analyzer ON, all the necessary connections were made;

- The oxygen sensor is connected

- The water trap and probe line are empty of water

- The paper roll is fitted

- The flue temperature sensor is connected

- The remote lead socket is connected to the handset lead.

- The hose from the water trap connector is attached to the water trap and out to the analyzer probe

- The oxygen sensor is connected

- The water trap and probe line are empty of water

- The paper roll is fitted

- The flue temperature sensor is connected

- The remote lead socket is connected to the handset lead.

- The hose from the water trap connector is attached to the water trap and out to the analyzer probe.

- The instrument was placed on a clean flat level surface.

The switch on the handset is then pressed ON, and the analyzer then calibrates itself automatically for 290 to 300 seconds.

After calibration, the probe on the analyzer is then inserted into the exhaust of a working generator (for the sake of this project TATA and PERKINS exhausts).

On the handset, function two (Quintox control) is then selected using the down scroll key, enter key is then pressed to access the Quintox control. 
Also, a trigger on the probe is then pressed hard to allow the air to pass through it to the analyzer. Fuel is next displaced, and natural gas (diesel) is then selected and enter key pressed. The probe still on hold in the exhaust, on the handset screen, page mode select (function one) is then selected, enter key then pressed. This screen shows the readings whose accessories are attached, those functions with sensors not attached shows NOT FITTED.

Finally, a print option from the handset is then pressed, and then values are printed from the printer on the exhaust analyzer. The probe is then removed from the exhaust and allowed to cool before it is disassembled.

Above is the procedure done to both TATA and PERKINS generators.

$\begin{array}{ll}\text { 1st Reading } & \\ \text { O2 }(\%) & 17.0 \\ \text { CO }(\mathrm{ppm}) & 455 \\ \text { EFF }(\mathrm{G})(\%) & 63.8 \\ \text { XAIR }(\%) & 448 \\ \mathrm{CO} 2(\%) & 2.2 \\ \mathrm{CO} / \mathrm{CO} 2 \mathrm{R} & 0.0206 \\ \text { PI }(\%) & 2.06 \\ \text { NETT C } & 150.5 \\ \text { FLUE C } & 184.4 \\ \text { AMBIENT C } & 33.9\end{array}$

Table (I ) for PERKINS

$\begin{array}{llll}\text { 2nd Reading } & & \text { 3rd Reading } & \\ \text { O2 }(\%) & 17.0 & \text { O2 }(\%) & 16.8 \\ \text { CO }(\mathrm{ppm}) & 508 & \text { CO }(\mathrm{ppm}) & 519 \\ \text { EFF }(\mathrm{G})(\%) & 64.2 & \text { EFF }(\mathrm{G})(\%) & 65.0 \\ \text { XAIR }(\%) & 437 & \text { XAIR }(\%) & 417 \\ \mathrm{CO} 2(\%) & 2.2 & \mathrm{CO} 2(\%) & 2.3 \\ \mathrm{CO} / \mathrm{CO} 2 \mathrm{R} & 0.0230 & \mathrm{CO} / \mathrm{CO} 2 \mathrm{R} & 0.0225 \\ \text { PI }(\%) & 2.30 & \text { PI }(\%) & 2.25 \\ \text { NETT C } & 150.7 & \text { NETT C } & 151.2 \\ \text { FLUE C } & 184.9 & \text { FLUE C } & 186.1 \\ \text { AMBIENT C } & 34.2 & \text { AMBIENT C } & 34.9\end{array}$

\section{Table (II) for TATA}

$\begin{array}{ll}\text { 1st Reading } & \\ \text { O2 }(\%) & 17.0 \\ \text { CO }(\mathrm{ppm}) & 370 \\ \text { EFF }(\mathrm{G})(\%) & 70.7 \\ \text { XAIR }(\%) & 287 \\ \mathrm{CO} 2(\%) & 3.1 \\ \mathrm{CO} / \mathrm{CO} 2 \mathrm{R} & 0.0119 \\ \mathrm{PI}(\%) & 1.19 \\ \text { NETT C } & 153.8 \\ \text { FLUE C } & 196.7 \\ \text { AMBIENT C } & 42.9\end{array}$

\begin{tabular}{ll}
\multicolumn{1}{c}{ Table (II) for TATA } \\
2nd Reading & \\
O2 $(\%)$ & 15.6 \\
CO $(\mathrm{ppm})$ & 153 \\
EFF $(\mathrm{G})(\%)$ & 76.6 \\
XAIR $(\%)$ & 300 \\
CO2 $(\%)$ & 3.0 \\
CO/CO2 R & 0.0051 \\
PI $(\%)$ & 0.51 \\
NETT C & 106.6 \\
FLUE C & 149.8 \\
AMBIENT C & 43.2
\end{tabular}

$\begin{array}{ll}\text { 3rd Reading } & \\ \text { O2 }(\%) & 15.7 \\ \text { CO }(\mathrm{ppm}) & 314 \\ \text { EFF }(\mathrm{G})(\%) & 70.4 \\ \text { XAIR }(\%) & 306 \\ \mathrm{CO} 2(\%) & 2.9 \\ \mathrm{CO} / \mathrm{CO} 2 \mathrm{R} & 0.0108 \\ \text { PI }(\%) & 1.08 \\ \text { NETT C } & 150.5 \\ \text { FLUE C } & 193.8 \\ \text { AMBIENT C } & 43.3\end{array}$

\section{Discussions}

For the exhaust gas analysis, below is the discussion of the results obtained from the experiment.

$\square$ Oxygen $(\mathrm{O} 2)$ value in TATA increases steadily while in PERKINS, it is the same for the first two readings and fall in the third. Mean oxygen value for TATA is $[46.8 / 3=15.6 \%]$ and for PERKINS it is $[50.8 / 3=16.9 \%]$. This shows that TATA has lower oxygen mean percentage compared to PERKINS, and K. K. Jain and R. B. Asthana (2006) says higher oxygen percentage signifies higher combustion efficiency. Therefore, PERKINS has higher efficiency in contrast to TATA.

$\square$ carbon(iv)oxide (CO2) value in TATA decreases steadily, while in PERKINS, it is equal for the first and second readings and increases in the third. Average value for PERKINS is $[6.7 / 3=2.23 \%$ ) and $[9 / 3=3.0 \%]$ for TATA. Oxford medical dictionary, 6th edition (2002) and W. V. Mark and S. C. Bhatia (2007), highlights that carbon(iv)oxide stays in the air longer than the other compounds emitted from exhaust, and contributes more to greenhouse effect. TATA emits higher percentage, thereby making it more contributer to the greenhouse effect.

$\square$ Carbon monoxide (CO) value in TATA is higher in the first reading, decreases to less than half in the second reading and rise to more than twice the second reading in the third. In PERKINS however, it increases, but first to second increment is five times the second to third increment. Mean value in TATA is $[837 / 3=279 \mathrm{ppm}]$ and for PERKINS it is $[1482 / 3=494 \mathrm{ppm}]$. Oxford medical dictionary, 6th edition (2002) explain that carbon monoxide ( $\mathrm{CO}$ ) combines with haemoglobin (a substance contained within the red blood cells) and forms a chemical stable compound by name "carboxyhaemoglobin", thereby making the haemoglobin unable to combine with oxygen or take oxygen through the lungs and transport it within the body. From the mean value, PERKINS has higher emitted value.

$\square$ Average ambient air temperature for TATA is $[129.4 / 3=43.130 \mathrm{C}]$ and for PERKINS it is $[103 / 3=34.330 \mathrm{C}]$. This shows that the load imposed on TATA is higher to that imposed on PERKINS.

$\square$ Average percentage of combustion efficiency for TATA is [217.7/3 =72.6\%], and for PERKINS, it is [193/3 $=64.3 \%$, showing higher average value in TATA compared to PERKINS 
In TATA, thou, oxygen value for the three readings increases steadily, the efficiency of combustion shows no steady increment (fluctuates). In PERKINS however, the efficiency increases steadily, showing that there isproper maintenance (engine does not wear beyond acceptable limits before repair, or engine oil does not enter engine path ways) in PERKINS compared to TATA.

In general, since all of them emits CO far below the acceptable emission limit, all are fit for use.

V.A.W. Hillier (1993) says the emission limits for diesel Engines based on European Emission Standard (EEC) directive 70/156/EEC (88/77/EEC) for new designs of diesel Engines starting from July, 1st 1988 is:

\section{Mass of Co $(\mathrm{g} / \mathrm{kwh})$ \\ 11.2}

\author{
Mass of HC \\ $(\mathrm{g} / \mathrm{kwh})$ \\ 2.4
}

\author{
Mass of Nox \\ $(\mathrm{g} / \mathrm{kwh})$ \\ 14.4
}

\section{Conclusion}

\section{Conclusion And Recommendation}

Exhaust components from TATA and PERKINS diesel engine generators are sources of air pollution.

From this experiment, the exhaust gas analysis shows that, carbon monoxide (co) value for TATA is 279ppm and for PERKINS, it is 494ppm, showing higher carbon monoxide emission from PERKINS generator exhaust. In $\mathrm{g} / \mathrm{kwh}$, TATA value is $0.70 \mathrm{~g} / \mathrm{kWh}$ and PERKINS value is $1.17 \mathrm{~g} / \mathrm{kWh}$. It is observed that both TATA and PERKINS emits for below the emission limits which is $11.2 \mathrm{~g} / \mathrm{kwh}$, thereby making them fit for use.

Furthermore, since these gases are carcinogenic and cause chest related disease as observed by Intergovernmental panel on climate change (IPCC) in 1988 by World Meteorological Organization (WMO) and United Nations Environment programme (UNEP), below are a few suggestions as regards to ways of reducing the menance to the bearest minimum:

\section{Recommendation}

Since these emitted gases are toxic to both human health and the environment at large, below are some recommendations to reduce its emission to the barest minimum. The government, related NGO'S and other stake- holders should:

i. Impose a compulsory regular machine and vehicle emission tests and stop those due for retirement.

ii. Provide permits to operate industrial power generators and oil refining facilities, and impose periodic check, renewal and modification of equipment on the industries and refineries.

iii. Ban or regulate the sale of certain fuels and require the use of cleaner fuels.

iv. In collaboration with youth organizations increase the level and strength of community compelling against new fossil fuel developments with high greenhouse gas pollution levels.

v. Partner with international Scientist research organizations to fully assess the impact of climate change on worldwide plants, animals and Ecosystems and identify measures to avoid irreversible damage.

vi. Undertake a major reform of the Electricity industry to encourage greater uptake of renewable Energy and a decline in the share of power provided by coal .

vii. Limit the use of chimneys and other forms of biomass burning in urban and rural areas.

viii School should encourage students that have interest in Energy, especially renewable Energy by enriching the libraries with related books for research.

\section{Emission Limit For PERKINS}

\section{Appendix}

\section{$\mathrm{CO}=279 \mathrm{ppm}$}

Molar mass of $\mathrm{CO}=12+16=28 \mathrm{~kg} / \mathrm{mol}$

Flow rate $=24 \mathrm{~m} 3 / \mathrm{min}$

Molar volume $=22.414 \mathrm{~m} 3 / \mathrm{kgmol}$

Engine speed $=12 \mathrm{kw}$

$(279 * 24 * 1 * 28 * 1000 \mathrm{~g}) /(10 \mathrm{E} 6 * 22.414 * 1 * 1 \mathrm{hr})$

$=8.36 \mathrm{~g} / \mathrm{hr}$

$=8.36 / 12$

$=0.70 \mathrm{~g} / \mathrm{kwh}$

\section{Emission Limit For TATA}

$\mathrm{CO}=494 \mathrm{ppm}$

Molar mass of $\mathrm{CO}=12+16=28 \mathrm{~kg} / \mathrm{mol}$

Flow rate $=22.8 \mathrm{~m} 3 / \mathrm{min}$ 
Molar volume $=22.414 \mathrm{~m} 3 / \mathrm{kgmol}$

Engine speed $=12 \mathrm{kw}$

$(494 * 22.8 * 1 * 28 * 1000 \mathrm{~g}) /(10 \mathrm{E} 6 * 22.414 * 1 * 1 \mathrm{hr})$

$=14.07 \mathrm{~g} / \mathrm{hr}$

$=14.07 / 12$

$=1.17 \mathrm{~g} / \mathrm{kwh}$

\section{References}

[1]. Arthur, S. and Chaim. G. (2009). Thermodynamics from concept to applications, Second Edition, Taylor and Francis group, (CRC Press), London.

[2]. Dara, S.S (2006). A textbook of Environmental chemistry and pollution control, S.Chand and Company limited, New Delhi.

[3]. Douet .J, (1998). Going up in smoke. The history of the industrial chimney, Victoria society, London.

[4]. Dabelstein, w. Arno, R., Schutze, A., and Klauss R., (2007), Automotive fuels in Encyclopedia of industrial chemistry. John Wiley and son $\square$ s Inc, weinheim.

[5]. Goldberg, D. (2006). Fundamentals of Chemistry, Fifth Edition. Mc Graw Hill, London.

[6]. Hillier, V.A.W, (1993) Fundamentals of vehicle technology, fourth Edition.F.W pit tuck books publishers, Nelson Thorns Itd. New York.

[7]. Holman, J.P., (1998). Thermodynamics, fourth Edition, Mc Graw Hill, London.

[8]. IPCC (2007). Climate change 2007. The scientific basis.

[9]. James. O., (1999). Handbook of chemical Engineering Research and Education Association Mc Graw Hill, London.

[10]. Kenneth, w, and Donald,R. (1999). Thermodynamics sixth edition, Mc-Graw hill, London.

[11]. Kane M. (2008). Exhaust gas analyzer km9106 operator $\square$ s guide. Hertfordshire.

[12]. Mark, W.V and Bhatia, S.C (2007). Chemical process industries, volume II, Second Edition, CBS Published and distributors, New Delhi.

[13]. Nauss K. M (1997). A critical analysis of Emissions, exposure and health Effects. Dieselnet technical report

[14]. Olah, G.A, Geoppert, A., and Prakash, G.K (2006). Beyond oil and Gas. The methanol Economy. John Wiley and Sons Inc, Weinheim.

[15]. Olander D.R, (2008). General Thermodynamics, Taylor and Francis group, CRC Press, London.

[16]. Oxford Medical Dictionary (2002). Sixth Edition oxford university press, London.

[17]. Singh, K.P (2004).Automobile engineering volume II, standard publishers $\square$ distributions, khanna, New Delhi.

[18]. Steenland, K., Silverman, D.T, and Zaebest D., (1992) Exposure to diesel exhaust in the trucking industry and possible relationships with lung cancer. American journal of industrial medicine.

[19]. Jain, k.k. and Asthana, R.B (2006). Automobile Engineering, Tata Mc Graw Hill, New Delhi.

[20]. Yunus, A., and Robert, H (2001).Fundamentals of Thermal-Fluid Sciences.

[21]. Mc-Graw Hill, London. 